\title{
Hubungan antara Kadar Asam Urat, Interleukin-6 dan hs-CRP pada Anak Obes
}

Yohanes Santoso, Sarah M Warouw, Jose M Mandei, Praevillia Salendu

Bagian Ilmu Kesehatan Anak Fakultas Kedokteran Universitas Samratulangi/Rumah Sakit Prof. Dr.R.D. Kandou, Manado

Latar belakang. Hubungan antara kadar asam urat dengan sindrom metabolik banyak diteliti akhir-akhir ini. Asam urat juga menghambat proliferasi sel endotel dan menstimulasi produksi C-reactive protein (CRP) pada sel endotel. Interleukin-6 (IL-6) berasal dari jaringan adiposa yang menyebabkan peningkatan CRP.

Tujuan. Menganalisis hubungan antara kadar asam urat, IL-6, dan hs-CRP pada anak obes.

Metode. Kami melakukan penelitian potong lintang pada bulan Oktober 2015 sampai Desember 2015. Subyek anak obes berumur 6-12 tahun. Informed consent diberikan oleh orang tua. Penelitian ini telah disetujui oleh Komite Etik penelitian FK Unsrat. Hubungan antara asam urat, IL-6, dan hs-CRP diuji dengan uji Pearson dan regresi linear. Data dianalisis dengan software SPSS versi 22.0, nilai $\mathrm{p}<0,05$ signifikan.

Hasil. Terdapat 43 anak obes, 60.5\% laki-laki, dan 39.5\% perempuan. Hubungan asam urat dan hs-CRP didapatkan r=0,458 dan $\mathrm{p}=0,001$, sedangkan hubungan IL- 6 dan hs-CRP didapatkan hasil $\mathrm{r}=0,331$ dan $\mathrm{p}=0,015$.

Kesimpulan. Terdapat hubungan positif antara asam urat dan hs-CRP, hubungan positif lemah antara IL-6 dan hs-CRP pada anak obes. Sari Pediatri 2016;18(4):320-4

Kata kunci: asam urat, interleukin-6, hs-CRP

\section{Relationship between Uric Acid, Interleukin-6, and hs-CRP in Obese Children}

Yohanes Santoso, Sarah M Warouw, Jose M Mandei, Praevilia Salendu

Background. The relationship between uric acid with metabolic syndrome has been researched lately. Uric acid also inhibits endothelial cell proliferation and stimulates the production of C-reactive protein (CRP) in endothelial cells. Interleukin-6 (IL-6) derived from adipose tissue and leads to an increasing CRP.

Objective. To analyze the relationship between uric acid, IL- 6 and hs-CRP in obese children.

Method. We conducted a cross-sectional study in October 2015 until December 2015. The subject were obese children aged 6-12 years. Informed consents were obtained from the parents. This study has been approved by Samratulangi research ethics committee. The relationship between uric acid, IL- 6 and hs-CRP were tested with Pearson and linear regression. Data were analyzed with SPSS software version 22.0, p value $<0.05$ was significant.

Results. There were 43 obese children, 60.5\% male, and 39.5\% female. The relationship between uric acid with hs-CRP showed $\mathrm{r}=0.458$ and $\mathrm{p}=0.001$. The relationship between IL- 6 with hs-CRP showed $\mathrm{r}=0.331$ and $\mathrm{p}=0.015$.

Conclusion. There is positive relationship between uric acid with hs-CRP, and between IL- 6 with hs-CRP in obese children. Sari Pediatri 2016;18(4):320-4

Keywords: uric acid, interleukin-6, hs-CRP

Alamat korespondensi: Dr. Yohanes Santoso. Bagian Ilmu Kesehatan Anak Fakultas Kedokteran Universitas Samratulangi/Rumah Sakit Prof Dr.R.D. Kandou Jl. Raya Tanawangko, Manado. Email: yohan86eccentri@yahoo.com 


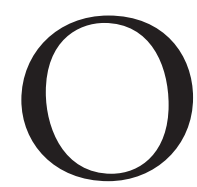

besitas merupakan epidemi yang berkembang cepat di seluruh dunia sehingga meningkatkan risiko morbiditas dan mortalitas. ${ }^{1}$ Berdasarkan data riset kesehatan dasar, angka kejadian gizi berlebih pada anak usia kurang dari 5 tahun di Indonesia 12\% di perkotaan maupun pedesaan, pada anak usia 6-14 tahun $9 \%$ di perkotaan dan $7 \%$ di pedesaan. Di Kota Manado dilaporkan 13,7\% anak obes yang berumur 6-14 tahun. $^{2}$

Hubungan antara kadar asam urat dengan sindrom metabolik banyak diteliti akhir-akhir ini. Studi epidemiologi menyatakan hubungan erat antara kadar asam urat dan tanda sindrom metabolik pada anak dan remaja. ${ }^{3}$ Kadar asam urat yang tinggi dapat menghambat proliferasi sel endotel dan menstimulasi produksi $C$-reactive protein (CRP) pada sel endotel. ${ }^{4}$ High sensitive c reactive protein (hsCRP) merupakan CRP yang ditentukan berdasarkan highly sensitive assay dan merupakan acute phase reactant yang diproduksi oleh hati dibawah kontrol Interleukin-6 (IL-6) sehingga dapat digunakan untuk mengukur inflamasi akut maupun inflamasi kronik. ${ }^{5}$ Interleukin- 6 berasal dari jaringan adiposa viseral yang menyebabkan peningkatan produksi CRP di hati. ${ }^{6}$ Tujuan dari penelitian ini untuk mengetahui hubungan antara kadar asam urat dengan hs-CRP dan hubungan antara IL-6 dengan hs-CRP pada anak obes.

\section{Metode}

Penelitian dilakukan dengan metode analitik pendekatan potong lintang pada anak obes. Penelitian dilakukan dari bulan Oktober 2015 sampai dengan Desember 2015. Subjek penelitian adalah anak SD berusia 6-12 tahun dengan obesitas di Kecamatan Tuminting kota Manado yang memenuhi kriteria inklusi dan eksklusi. Kriteria inklusi adalah usia anak 6-12 tahun dengan obesitas sesuai kurva IMT/U CDC 2000, tidak mengalami inflamasi akut dalam 2 minggu terakhir, dan orang tua menyetujui untuk ikut serta dalam penelitian dengan menandatangani informed consent. Kriteria eksklusi adalah anak yang sedang menderita penyakit ginjal (sindrom nefrotik, glomerulonephritis akut), dengan gangguan fungsi hati, dan tidak mengkonsumsi obat-obatan penurun panas, anti nyeri, antibiotik dalam 2 minggu terakhir. Penelitian dilaksanakan atas persetujuan Komite Etik FK Unsrat. Analisis data secara komputerisasi menggunakan perangkat lunak SPSS versi 22.0 Analisis yang digunakan adalah analisis regresi linear dan analisis korelasi Pearson.

\section{Hasil}

Terdapat 180 anak obes di Kecamatan Tuminting. Setelah dilakukan randomisasi didapatkan 43 anak obes, 26 (60,5\%) anak laki-laki dan 17 (39,5\%) anak perempuan. Hasil karakteristik subjek penelitian tertera pada Tabel 1 .

Berdasarkan hasil analisis korelasi Pearson, hubungan asam urat dengan hs-CRP pada sampel penelitian, didapatkan $r=0,458$ dan $p=0,001$.

Berdasarkan hasil analisis korelasi Pearson, hubungan IL-6 dengan hs-CRP pada anak obes, didapatkan $\mathrm{r}=0,331$ dan $\mathrm{p}=0,015$.

Tabel 1. Karakteristik subyek penelitian

\begin{tabular}{lccc}
\hline Karakteristik & Rerata & Median & IK95\% \\
\hline Usia & 9,63 & 10 & $9,22-10,03$ \\
Berat badan $(\mathrm{kg}))$ & 57,69 & 54 & $51-57,69$ \\
Tinggi badan $(\mathrm{cm})$ & 134,98 & 136 & $131,93-138,02$ \\
Indeks massa tubuh & 29,44 & 28 & $28,61-30,28$ \\
Asam urat & 5,8 & 5,6 & $5,5-6,1$ \\
IL-6 & 2,4 & 2,0 & $1,9-2,9$ \\
hs-CRP & 4,2 & 3,3 & $3,3-5,1$ \\
\hline
\end{tabular}




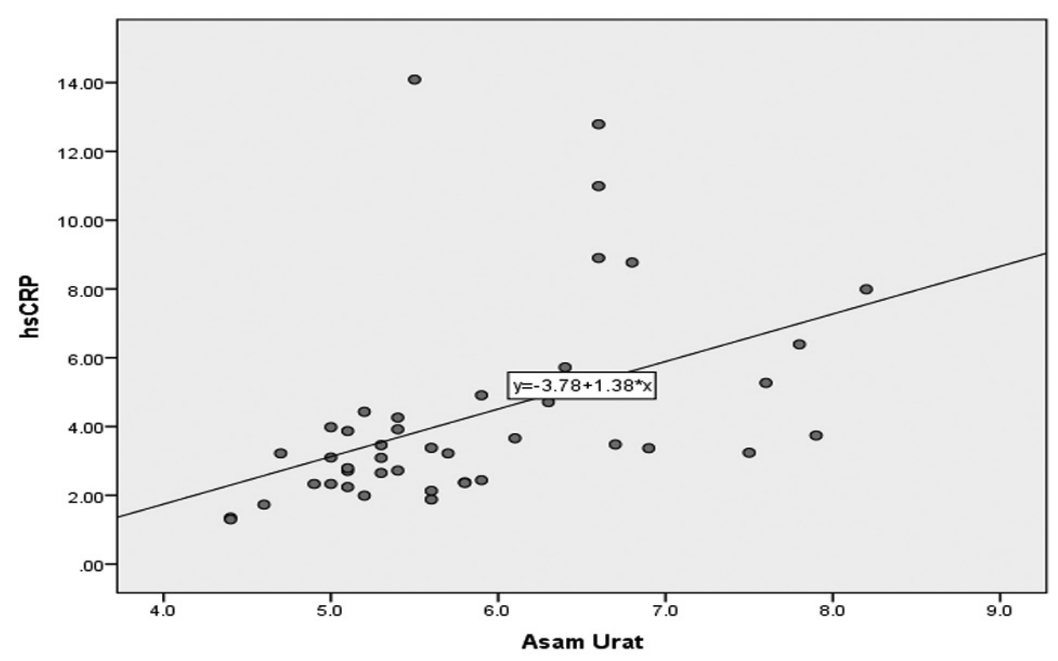

Gambar 1. Scaterplot hubungan asam urat dan hs-CRP pada anak obes.

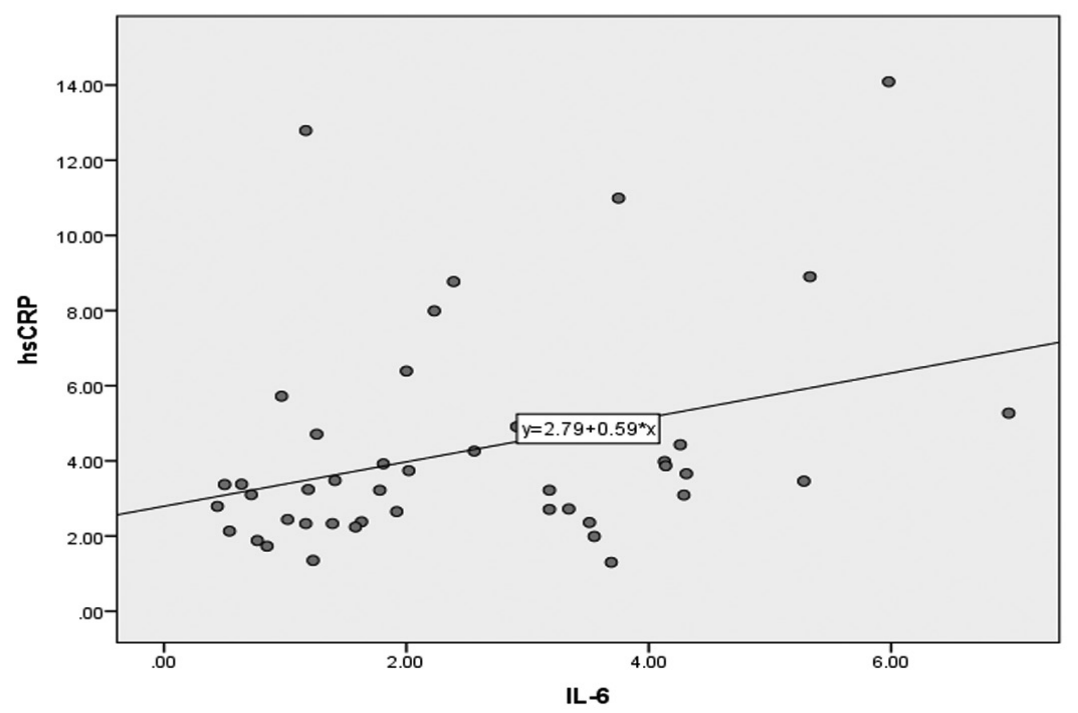

Gambar 2. Scaterplot hubungan IL-6 dan hs-CRP

\section{Pembahasan}

Obesitas merupakan masalah kesehatan dunia pada anak dan remaja yang semakin sering ditemukan di berbagai negara. Beberapa penelitian epidemiologi telah menunjukkan hiperurisemia sebagai faktor risiko dari penyakit kardiovaskular pada populasi secara umum. ${ }^{7,8}$ Asam urat diketahui sebagai antioksidan dan mungkin antioksidan paling penting dalam plasma dengan kontribusi sampai $60 \%$ dari seluruh aktivitas pembersihan radikal bebas dalam serum manusia., ${ }^{9} 10$ Namun demikian, asam urat juga bersifat prooksidatif pada kondisi tertentu. Observasi klinis dan laboratoris memperlihatkan peningkatan konsentrasi asam urat lebih dari $5,5 \mathrm{mg} / \mathrm{dL}$ dikaitkan dengan disfungsi endotel. ${ }^{11}$

High-sensitivity c-reactive protein merupakan pemeriksaan yang dapat mengukur konsentrasi CRP yang sangat sedikit sehingga lebih sensitif dengan jarak pengukuran antara 0,1-20 mg/L. High sensitivity 
c-reactive protein ini baik untuk memeriksa adanya inflamasi derajat rendah. ${ }^{12}$ Menurut laporan Visser $\mathrm{dkk},{ }^{13}$ peningkatan konsenstrasi CRP serum dapat memprediksi risiko penyakit jantung koroner pada masa depan.

Hasil analisis regresi linear hubungan asam urat dan hs-CRP pada anak obes menunjukkan hubungan yang bermakna $(r=0,458$ dengan $p=0,001)$. Hal ini mendukung laporan penelitian yang dilakukan Kang $\mathrm{dkk}^{14}$ pada sel otot polos vaskular yang diberikan asam urat dengan kadar 0,6-12 mg/dL. Didapatkan hasil sel otot polos vaskular memroduksi CRP pada kadar asam urat $6 \mathrm{mg} / \mathrm{dL}$. Pada anak obes dengan kadar asam urat yang lebih tinggi dari normal dapat menstimulasi CRP. Valle $\mathrm{dkk}^{15}$ melakukan penelitian hubungan asam urat dan hs-CRP pada anak usia 6-9 tahun. Didapatkan hasil hubungan lemah asam urat dan hs-CRP ( $\mathrm{r}=0,3375, \mathrm{p}=0,027)$.

Jaringan adiposa dikenal sebagai penghasil IL-6 serum terbanyak, sekitar 25\% dari total IL-6 serum. Dengan peningkatan jaringan adiposa maka produksi IL-6 juga meningkat. ${ }^{16}$ Hasil analisis regresi linear hubungan IL-6 dan hs-CRP pada anak obes menunjukkan hubungan positif lemah. Hal ini sesuai dengan penelitian yang dilakukan oleh Browning $\mathrm{dkk}^{17}$ yang melaporkan bahwa IL-6 berhubungan kuat dengan kadar hs-CRP $(r=0,33, p<0,05)$. Pradhan $\mathrm{dkk}^{18}$ juga melaporkan bahwa kadar IL-6 berhubungan erat dengan kadar hs-CRP $(\mathrm{r}=0,39, \mathrm{p}<0,001)$. Bastard $\mathrm{dkk}^{19}$ juga melaporkan hasil adanya hubungan positif yang sangat kuat antara IL- 6 dan hs-CRP ( $r=0,683$, $\mathrm{p}<0,001)$. Peningkatan IL-6 pada obesitas yang menyebabkan terjadinya peningkatan produksi CRP di hati menandakan telah terjadinya inflamasi derajat rendah yang kronis, yang akan menyebabkan terjadinya disfungsi endotel dan selanjutnya menyebabkan sindrom metabolik, aterosklerosis, dan berbagai komplikasi lainnya. ${ }^{19,20}$

Hasil penelitian ini dapat memberikan masukan kepada para pekerja kesehatan bahwa telah terjadi inflamasi kronis derajat rendah pada anak obes berusia 6-12 tahun dan hal ini merupakan faktor risiko terjadinya kelainan kardiovaskular, sindrom metabolik, dan berbagai komplikasi di kemudian hari yang memerlukan intervensi dini. Pemahaman akan hal ini bagi para anak obes beserta orang tua mereka akan meningkatkan kesadaran untuk memperbaiki pola hidup melalui perbaikan diet dan peningkatan aktivitas fisik.
Penelitian telah menunjukkan bahwa penurunan berat badan yang signifikan dihubungkan dengan konsentrasi yang lebih rendah dari CRP, sitokin, dan molekul adhesi sehingga mengindikasikan penurunan status inflamasi keseluruhan dari individu. ${ }^{16}$ Selvin $\mathrm{dkk}^{21}$ melaporkan bahwa untuk setiap $1 \mathrm{~kg}$ kehilangan berat badan, perubahan rata-rata dari kadar total CRP adalah $-0,13 \mathrm{mg} / \mathrm{L}$. Wong $\mathrm{dkk}^{22}$ melaporkan bahwa penurunan berat badan yang lebih besar dihubungkan dengan penurunan yang lebih besar dari IL-6 dan CRP.

Keterbatasan dari penelitian ini adalah tidak dilakukannya penelusuran lebih lanjut mengenai aktivitas fisik dan pola hidup anak obes dalam penelitian ini.

\section{Kesimpulan}

Berdasarkan hasil ini penelitian ini dapat disimpulkan bahwa terdapat hubungan positif antara asam urat dengan hs-CRP pada anak obes dan terdapat hubungan lemah antara IL-6 dengan hs-CRP pada anak obes.

\section{Daftar pustaka}

1. Kosti RI, Panagiotakos DB. The epidemic of obesity in children and adolescents in the world. Cent Eur J Publ Health 2006;14:151-9.

2. Badan Penelitian dan Pengembangan Kesehatan Departemen Kesehatan RI. Riset Kesehatan Dasar (RISKESDAS) 2007. Jakarta: Kemenkes RI;2007.h.34-60.

3. Oliveira EP, Burini RC. High plasma uric acid concentration: causes and consequences. Biomed Central 2012;4:1-7.

4. Billiet L, Doaty S, Katz JD, Velasquez MT. Review of hyperuricemia as new marker for metabolic syndrome. ISRN Rheumatol 2014;10:1-7.

5. Abraham J, Campbell CY, Cheema A, Gluckman TJ, Blumenthal RS. C-reactive protein in cardiovascular risk assessment: a review of the evidence. J Cardiometab Syndr 2007;2:119-23.

6. Chase HP, Cooper S, Osberg I, Stene LC, Barriga K, Norris $\mathrm{J}$, dkk. Elevated c-reactive protein levels in the development of type-1 diabetes. Diabetes 2004;53:2569-73.

7. Pacifico L, Cantisani V, Anania C, Bonaiuto E, Martino F, Pascone R, dkk. Serum uric acid and its association with metabolic syndrome and carotid atherosclerosis in obese children. Eur J Endocrinol 2009;160:45-52.

8. Kannelis J, Kang DH. Uric acid as a mediator of endothelial 
dysfunction, inflammation, and vascular disease. Seminars in Nephrology 2005;25:39-42.

9. Waring WS, Webb DJ, Maxwell SR. Uric acid as a risk factor for cardiovascular disease. Q J Med 2000;93:707-13.

10. Johnson RJ, Kang DH, Feig D, Kivlighn S, Kanellis J, Watanabe $S, \mathrm{dkk}$. Is there a pathogenetic role for uric acid in hypertension and cardiovascular and renal disease. Hypertension 2003;41:1183-90.

11. Culleton BF, Larson MG, Kannel WB, Levy D. Serum uric acid and risk for cardiovascular disease and death: The Framigham Heart Study. Ann Intern Med 2006;131:7-13.

12. Silva D, Lacerda AP. High sensitivity c-reactive protein as a biomarker of risk in coronary artery disease. Rev Port Cardiol 2012;31:733-45.

13. Visser M, Bouter LM, McQuillan GM, Wener MH, Harris TB. Low grade systemic inflammation in overweight children. Pediatrics 2001;107:13-9.

14. Kang DH, Park SK, Lee IK, Johnson RJ. Uric acid induced c-reactive protein expression: implication on cell proliferation and nitric oxide production on humarn vascular cells. J Am Soc Nephrol 2005;16:3353-62.

15. Valle M, Martos R, Canete, Valle R, van Donkelaar EL, Bermudo F, dkk. Association of serum uric acid levels to inflammation biomarkers and endothelial dysfunction in obese prepubertal children. Pediatric Diabetes 2014;10:1-7.

16. Bruun JM, Verdich C, Toubro S, Astrup A, Richelsen B. Association between measures of insulin sensitivity and circulating levels of interleukin-8, interleukin-6 and tumor necrosis factor- $\alpha$. Effect of weight loss in obese men. Eur J Endocrinol. 2003;148:535-42.

17. Browning LM, Krebs JD, Magee EC, Fruchbeck G, Jebb SA. Circulating markers of inflammation and their link to indices of adiposity. Obes Facts 2008;1:259-65.

18. Pradhan AD, Manson JE, Rifai N. C-reactive protein, interleukin- 6 and risk of developing type 2 diabetes mellitus. JAMA 2001;286:327-34.

19. Bastard JP, Jardel C, Bruckert E, Blondy P, Capeau J, Laville M, dkk. Elevated levels of interleukin 6 are reduced in serum and subcutaneous adipose tissue of obese women after weight loss. J Clin Endocrinol Metab 2000;85:3338-42.

20. Berg AH, Scherer PE. Adipose tissue, inflammation, and cardiovascular disease. Circ Res 2005;96:939-49.

21. Selvin E, Paynter NP, Erlinger TP. The effect of weight loss on c-reactive protein. Arch Intern Med 2007;167:31-9.

22. Wong E, Freiberg M, Tracy R, Kuller L. Epidemiology of cytokines. Am J Epidemiol 2008;168:443-53. 